\title{
研究会報告
}

\section{低温亡安全 性*}

(昭和 43 年 3 月 23 日)

\begin{tabular}{|c|c|c|c|c|c|c|c|c|}
\hline 石 & 井 & 尚 & 道（高 & 不保安協会) & 佐 & 藤 & 禎 & 司 (日本酸 素) \\
\hline (司会)大 & 島 & 患 & 一（東 & 工) & 等 & 々 力 & & 達（電 気 試 験 所） \\
\hline 北 & $川$ & 徹 & 三（安 & 工学 劦会) & 外 & 山 & & 昭（神 戸 製 鋁 \\
\hline & 林 & 嶺 & 夫（東 & 温センター） & 早 & & 啓 & 一（東大物性研㶢所） \\
\hline
\end{tabular}

一般的考察

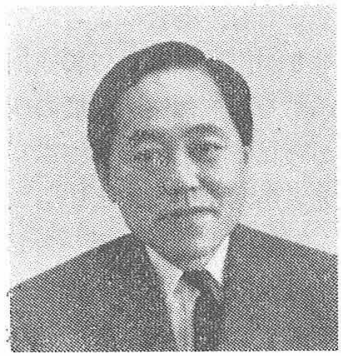

大島恵一氏
最近日本でも低温，特 飞低い温度の装監が出来 て宗いり势すし，禁た， 液体窒素, 水素, ヘリウ ム、メタンというような 非常に低い温度の液体の 液化, 貯藏や輸送関係の 機器がふえてまいりまし たので，いろいろと安全 の問題が出てきて㐨ります。アメリなどでは安全の 問題性相当汇重要視して，たとえば，低温工学の学会 飞安全のセクションがありまして，いるいると討諭し ているよらですが，日本では中現在のとこう技術が新し

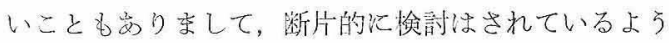
ですがままをまた会合慓ございません。これはぜひ 進めなけ机ばならない大切な間題なので，第一回とし て比較的関係の深い万及限定して，扮集まりいただ き季して，討論会を開き，これを会誌に载也て，こう いった気浬を高めたいと思ってい票す。進め方といた しましては, 最初概括的な問題を申乙上げて, 次に各 論的な問題として, 低温ガス分離工業の関係及び低温

:これは，3月 23 日低温工学協会によって開かれた 低温と安全に関するパネルディスカッションを再㙇 したものです。把世話いただいた東大工学部原子力 工学科の松原洋一氏に深く感謝いたします。

Vol. 3 No. 4 (1968)
大島恵 一

装置関倸を日本酸素の佐藤さん，神戸裂鋼の戸山さ ん，患心実際汇実騟室で液体へリウムその他を取り扱 っている例として，東大低温せンターの小林さんと物 性研の早吸さん，最近非常に問題になっている超電導

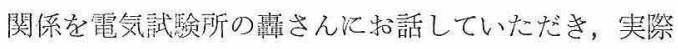
の法規的な問題については保安劦会の石井さんと最後 に安全の間題の考光方をどらするか，といった管理的 問題火関連して, 安全協会から横浜大学の北川先生沉 蛒話していただくことにしたいと思います。

そず手炲めに概括的な問題として申し上げすすと, 低温工学は非常に進歩が早い, 新しい分野ですから, 安全の開題はどちらかというと, 取り残されてしない ます。たと竞ば, 研究開発として大型の液体水素泡箱 を作ることが日本でも進んで括りますが，それに従う 大量の液体水素取报いに関与る危険については，法規 的にもつめたものがないという状態です。

ふた，個々の研究室ではそれぞれ安全について注意 して扮られ李すが，一般的規定といったなとまった形 のものがない。最初にパイオニア的低温を開発した グループは比校的神経質に注意をして, 砳究室内の規 定がありますけれども，あとから，低温を便うという 場合には，そこ束で険討している㗇がないといらので 安全火は手がまわらぬといらのが現状でないかと思 いをす。

これは一つ《は考方方の問題で, 物性研で日本で最 
初に相当量の液体水素を作る時に, 有名なジョークを 訪小て問題をいろいろ聞きましたら，ちょうど新しい ビルを建てていたのですが，空の外を指して，ビルが 出来るまであの上から一人や二人落ちてけがをする人 もいるんだから，掠ま光のところで新しい仕事をやる のに一人や二人けがするのはなんでもないだろう，と いう話で，市り相手にしてくれないで，液体水素の 爆発はここの研究室で度々やっているけれども, まゆ 毛を焦すぐらいだから心配するな，という話で㲕んで しまいました。

本当に，先端的な仕事では安全ばかりをいっていら れないといらこともいえるかも知れません。しかし， これを小さな研究室でやっているらちはまだいいので すが, 数年前, アメリカの MIT とハーバード大学 の共同の加速器の泡箱が大爆発を起した有名な事故が あります。確か，三，三人の人が死に，大部けがをし ました。事故が起ってみると一人や二人はいいなどと はいっていられなくなり, 低温工学の会議に出ました ときも，NASAやAECの人たらは，大学でなかった らあんなことが起らないんだ，ということをいって いました。事実，この事故のためこのグループの水素 泡箱の計画は中止させられてしまいました。

いかに先端的な仕事でも，きちんとした安全の考慮 と管理がないと事故を起したときは非常に問題になり ます。実際に低温を扱う場合の安全に関しては二つの 面があると考えられます。一つには液体水素, ヘリウ ムというような今まであまり一般に报ったことのない 極低温の未知の分野にともなら危険です。

もう一つは, 未知ではないがいるいらと違った分野 のものが入ってくる。たとえば物理の測定をやってい る場合, 物理屋さんは物理的な立場から考えればどう いうものが危険だといらことが，わかっているわけで すが，そこに水素とか液体水素のような化学的な爆発 物が入っている。あるいは, 化学屋の方は水素の取り 扱いは慣れてますが，低温になったとさに金属が脆性 をもつというような材料上の間題, 岕るいは高圧や真 空を扱うといらようなことが入ってくる。このような 意味で低温工学の分野では, すでに他の専門の人には ある程度よくわかっているような危険が組合されて， この新しい分野に入ってさたためについ見落されて， 爆発なり事故を起すといら例があると思いすす。

この点での安全性は, 整理して考学てみれば，一つ 一つのものはそれ匡ど突拍子もないものではない。し かし，全体がまとまってまいりますと大きな危険があ

るという特徴があるのではないかと思います。物理的 には低温度で相変化が起るといったこと。液体が気体 に変るだけで $1 l$ ののが 700〜800 に, 千倍近くに なり, 常圧のものが 1000 気圧ぐらいに上がる。また 材料的な低温での性質がわかっていないために生ずる 問題，さらにまた，高圧や真空の一般的問題がありま す。これからパネルの方々からいろいると細かい具体 的なご経験を报話しいただけると思います。

最後に，二三私の経験を用いますと，酸素，窒素， 水素などを液体で扱うのですが，酸素に対しては，化 学の人は非常に気をつけて扱っていますが, 物理の人 はどららかというと，酸素をあまりこわいと思わない で, 液体水素に対しては非常に警戒心が強いというよ うなことがあります。大学の低温委員会などでも, 液 体水素については非常に規則がうるさいのですが, 液 体酸素のほうは空気がそこらにあるということで, 割 合と重要視されないのではないかという印象をもらま す。

さらに, 最近では大学その他でも液体窒素を使って いますが，窒素を使っていましても，場合によっては 液体窒素で冷やしているつもりが，空気が入って凝縮 して, 液体空気が入ることがある。液体窒素温度の所 へ空気が入ってくると，外から見ると水滴のように空 気が落ちてくる。最初は研究者が水が出る, といって いる5ちに良く調べますと, 空気が中にコンデンスし ていたわけで幸いにして早く見つけましたから事故が. なかったんですが，そこに綿がつめてあったので液体 空気とでは綿火薬及たいなことになり爆発の可能性が ある、といらわけです。こいらケースが比較的見の がされる危険があります。また, 最初物性研で液体水 素の装置を作り末したときに，水素を使うということ に関しましては，装置を製作していただいた日本酸素 の工員の方が試運転に水杯をしてこられたというぐら い危険を感じていたようです。ところが, 事実, 試運 転のときに小さな爆発が起ったわけです。原因は心配 した水素ではなく，実ほ液体窒素を減圧して温度を下 ザていたとき何回も液体窒素を繰り返し入れていたの ですが，入れ方が非常にまずかったために一種の蒸留 が行われ，最後のところへいって非常に酸素の濃い液 体が出来た。それを止めて, 中が蒸発してほとんど一 気压になって来たときに，真空ポンプでまた引いたわ けです。真空ポンプの油が不然性でなかったために, 真空ポンプで爆発が起った。これなどは実際液体水素 の方で非常に神経を使ったわけですが, 可然性の真空 
ポンプ油を使って，乙かも，液体窒素を供給したのに 後で考党ると爆発することは当然の上うな条件なんで ナが，気がつかないわけです。

また，固体の酸素が詰って括りますときに，液化機 なんかに無理に圧力をかけると爆発する。オックスフ ォ一ドで爆発したときに，固体の酸素が欠けるときに 爆発するんだということでした。果して固体の酸素が 液体水素の温度のとき結晶がこわされて，そこで爆 発するかどうかということはよくわかりま好んが， 一忘オックスフォードではそういら理由だといってま す。

最近では，フランスのサクレーで非常に大量の液体 水素が爆発した例があります。たまたまそのあとそこ へ行きましたので，話を聞いたところ，やはり原因が よくわからないが，酸素が入っていたらしいというこ とです。その時，たまたま上を飛行機が飛んでいたか ら、ショックウェーブか子知れないということを言っ ていましたがここれなんかも実際にどうして起ったか といらことがよくわからないケースであります。

また，この頃では常識的になって扣りますが，液体 窒素を放射線で照射して扣りますと，だんだんと水色 といいますか，紫色がついてまいりまして，これが有 機物に接触しますと爆発するわけです。これは窒素の アザイドではないかという説もありますし，一方，不 純物として入っている酸素がオゾンになっているんだ という説が㤁り李す。艺のために日本では原子炬の中 に液体窒素を入れることは許されて招りません。しか し，フランスでは液体公素を入れているわけです。を
して純度が高くさえあれば大丈夫たといらことで，非 常に高純度を保つ上うな形で入れて敊ります。これな んかの原因についてもいろいろと考党られて打ります が，はっきりしないようです。最初に予想されなかっ た液体窒素でも爆発するということが実際に起ったわ けです。また，超電導マグネットが最近でさて叔りま すが，超電導マグネットの場合には中に保持されてい るエネルギーは大変な量です。むれがいっぺんに出来 たら、どういうことになるかということが非常に間題

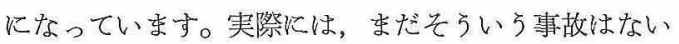
んですが，アメリカの会議では，このエネルギーが放 出されると，液体水素の爆発なんかよりもはるかに多 タの大きいエネルギーだといらことをいって物りまし た。

今までの例で申しましたように低温工学では, 非常 にいろいろな問題が錯綜しています。アメリカではマ ニアルを作ってをすが，唯マニアルを作るだけではい、 けないんで,たとえば,シカゴ大学では人間管理さえよ くやっていけば大丈夫だといっています。そこでは， 細かいことにあまり規制を強くすれば何もしないこと になってし慗うから，危くないときは非常にリラック スして，危い点で押觉る，という形で仕事をするとい ろことを強調して扣り末す。実際はそうなんでしょう が，そこまでもっていくにはいろいろな点で今後の研 究，岕いは専門・尃門のいろいろな経験を持ちよ。 て，それを整理していくということが必要だと思いま 寸。

\section{低温ガス分離工業に和ける事故例ととの安全対策}

佐藤 禎 司

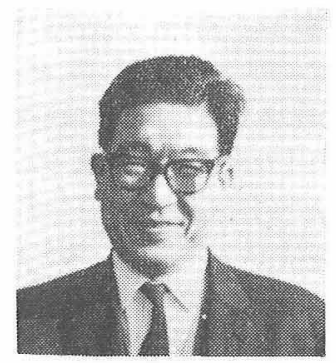

佐藤禎可氏
私に与兄られた課題は 空気分膗装置関係の安全 に対しててあります。空 気分離装置の発生する事 故は，装置の内部に起き るものと，外部に起さる ものとがあって,これは ほとんぞ酸素ガス，特に 高圧酸素㚙スによる事故 ですが，この二つに大別されます。
原因別沉いたしますと，化学的なものと，物理的な るのの二つに分けられます。

まず化学的な因子から申しますと, 第一に原料空気 中に含委れる不純物でありまして，その危険なものの 第一に挙げられるものはアセチレンであります。コン ビナート地区では含有率 1 PPM 位を対象にして対策 を立てよといわれて沶ります。次にNOであります。 これはこの次に挆話あるガス分離のほうで重要なこと でありますが，空気分離でもアセテレンと一緒になっ た場合に危険になるといわれて拉ります。第三に低級 
炭化水素，メタン，エチレンなどですが，二重結合が あるほうがより危険であるといわれています。

空気中含まれる不純物以外のものとしては，原料 空気を圧縮するとき，また膨張エンジンなどに使われ ます潤滑油が分離装置の中に入って，それが最終的に 液体酸素の溜に溜まる。さらにとれが液体酸素タンク の中に同伴するというのが問題となって呿ります。

それから空気分離装置は断熱材の中に入っているわ けでありますが，その断熱枋はもちろん不燃物でなけ ればならないわけですが，ものによっては若干油を含 んでいるものもありまして, 約 1.5 から 2 パーセント ぐらいの油を含むと酸素の中で燃光るという危険があ るといわれて和ります。

をた，最近のものでは改善され委したが，昭和 30 年 代にもございますが，装置を置く台として木材を多く 使って初りまして，液体酸素に触れると然光る危険が 宓ります。それで現在では一切木材のものを使わない 上らにして和り李すけれども，昔のものはそのま炕 なって呿りますので，このための事故が起きた例も岕 ります。以上が大体化学的なるのです。

物理的なるのとしましては，まず低温脆性によるも のです。これは装置の内部では大体銅，アルミニウム なぞ，低温脆性をもた好材料を用いるのが普通なので

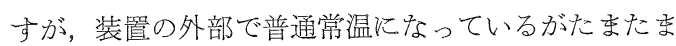
低温になるときがあるというときに，これがこわれて 非常に危険なことになる場合があります。特に液体酸 素系統でしかりであります。

特に高压酸素の中で摩擦熱によって危険なことにな る場合があります。鉄のサビが酸素の気流中で着火い たしまして，そのためにものを溶かす場合，溶かして 破裂する場合，あるいは鉄サビでなくとも粒子などに よる場合，あるいは回転体が和互いに接触する場合， いろいろな場合に摩擦熱が起こりまして大きな事故の 原因となるわけであります。

それで安全対策の潘うでありますが，吸入空気の不 純物に関しましては，一番簡単なのは吸入管を安全な 所へ伸ばす方法であります。外国のものでは風向きに よって二つの吸入管を切り替えるような場合もありま す。それからぞらしてる空気中の不純物が避けられな い場合は, 圧縮機の出口, 冷却器に入る前の高温状態 で触媒フィルターに通しまして, 反応でとってしまう といらものも㐫りすすしかし日本ではまだ実際に使 って招る例はないようでありますが，欧米では大体空 気分離器の数パーセントとか, 十数パーセント程度の
ものに触媒フィルターがついているといわれていま す。

もっとも一般的な方法としましては, 低温のゲルフ ィルタをつけるのが，か上らな異物をとる根本的な対 策でございまして，昭和 30 年ごろから液体空気汇 シリカゲルのフィルターをつけるように，法的にも定 められました。注とんぞの装置はとれがついているわ けですが，な招最近では液体酸素をポンプでサイクル させ主して，そのサイクルする中間にゲルフィルター をつけることも行なわれて物りをす。

それから油の対策といたしましては, 結局油が入ら ないようにフィルターその他で完全にキャッチすると いうこと以外はないわけですが，それ対しては時間 の関係上略させていただきすす。

空気分離装置のうち一番今問題度って赫りますの は，高圧酸素配管であります。高圧酸素配管の中のパ ッキングとして有機材料は使ってはいけないというふ らと決め机ば非常敒簡明でございまして，事実上私ぞ もの会社でもとらいう原則はありますが，たと光ばバ ルブのグランドのときは若干のテフロン材を使っても いいか，い惊いかというらうな間題がございます。

その次にいろいろな事故例でございますが，昭和39 年飞安全工学協会々硫安協会から, 空気分離装置の災 害事例調査という報告が出て和り变して，私がいま舟 し上げたことは活とんどその中に盛られて和りまして 特に興味を特持らの方はこ机を参照して頂きたく存じ 香专。

それによりますと空気分離器の懪発事故注從来通産 省㑢告されたるのは国内で全部で 37 例㐫ります。

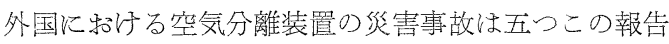
には出て特り李すが，これは外国のことでありますの で，岕るいはもっとあるんじやないかと思いすすが， その中でるっとも有名なのが，1961年にドイッのドル トムントで起き事した，空気 2 万立方米の装置の事故 であります。これでは死者 15 名を出してい宗す。こ れは先ほぞ申し末した，装置の架台に木老使って招っ た炕，その木に液体酸素がし反込几で，その前の部 分的な修理のために若干の溶接の火花が残っていて, それで大懪発を起こしたという例であります。

日本のものでは，人が死んだという例は汪とえで高 圧酸素の噴出による事故でございまして，1960年には 酸素のバルブが火を吹きむして，火傷致死となり，そ の時以来スルースバルブは使わない上うにしており拉り す。委た同じく 1960 年に酸素管をトリクレンで洗い 
そのトリクレンの液が残って抒りまして、トリクレン 々酸傩のガスによるガス爆発が起さて，その時以来酸 素管专洗うのはトリクレンでなく四塩化炭素にするこ とにはって扬りま京。气の翌年の1961 年には湿り酸 素を乾燥するゲル乾燥器が懪発して和り亦す。これは 粉末もしくは固体がパイプにぶつかりまして，そこで 火を出したものと考光られ束す。
な特この報告書の統計から見ますと，それの起きた 場所の分類がありまして，その件数として48 例の件 数中液体酸素の溜が爆発したのは，その半分の 24 例 を卢めて和りをす。

間題点の羅列になりをしてはなはだ取りとめ子ない のでございますが，いただいた時間も過ぎましたので この辺で。

\section{低温ガス分離装置の事故例とその妄全対策}

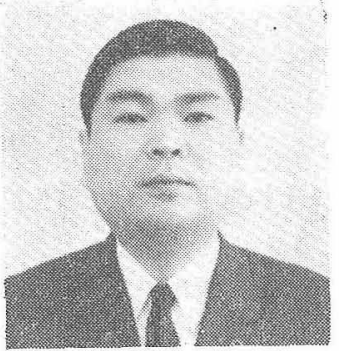

低温ガス分離装置とし て広く工業的澡業飞ら れてい当ものとしては液 体䇪素洗涤装置, メダン 分離装監，エチレン分離 装置, $\mathrm{CO}$ 分離装置, 高純 度 $\mathrm{H}_{2}$ 分離装置などが离 ります。まずこれらの装 外山昭氏 置の事故例で素り末すが 私の知る限りで手幾つかの大さな事故があり㿟す。た と究ばわが国では，ガ火の漏洩に上る引火から，負㑺者

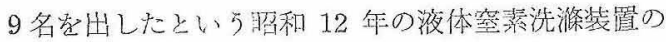
事故它始好々し, 昭和 19 年の高純度 $\mathrm{H}_{2}$ 型造装置の 2 回几及与爆発，昭和 34 年の液体空素洗湺装置の爆 発店ど十数例の事收が記録されて和ります。一力外国

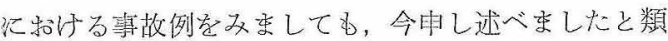
似の事故，たとえば 1930 年代のベルギー,フランス， ドイッの液体空素洗滌装置の相つぐ大懪発が報告され て特り，最近の例では，1958年の米国のコークス炬ガ ス一箜素洗滌装置, 1959年のオランダの液体空素洗浮

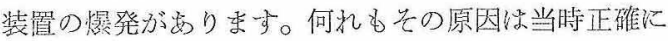
つかめざ，推測の域を出なかったものであり亦す。ま

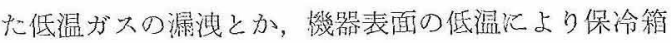
内の筀気が液化し，これと漏洩した可然性ガスとによ り爆発觉起したという 1957 年のカナダの水素精製装 置の嚗発など妇報告せられて杪ります。

このように取报らガスが可然性であるといら点で， 特に漏洩，爆発，発火などに対与る注意が，架気分離 装置よりも，よりシヴィアーであるという点で特黑性 があるとはい党，低温ガス分離装置の事故発生要因一 爆発，発火，破裂，空息，中毒，浨火傷など一そのも
外山昭

のは空気分離装置と全く同椂でありますので，ここで は言及すること省略いたします。

しかし，唯一つ特に採り上げて申し述べたいこと は，要る種の低温ガス分離装置の事故の中で，特異な 原因によって発生したと考克られる爆発について，横 浜国立大学北川教授のご指導の下に神戸䡈鍊所之横浜 国大北川研究室が其同で研密し，その結果，原因が始 めて解明せられましたので，この研究成果を簡単にご 報告し，ご参考化供したいと考光なす。林液体空 素洗源装置の幾つかの類似した爆発事故の原因につい てであります。

\section{基礎的研究とその結論}

さて, 液体室素洗㹋装置では, ガス中含をれるNO そジェン類との結合沈よって生じな物筫が何らかの原 因，特に加温操作中に分解して懪発学起すらしいとい うことは経験的推测として知られてきた。しかしこ

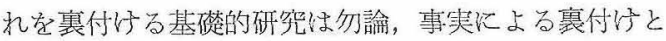
てなく，ましてや爆発物の生成機構，発火点てついて もすべて未知であったが，私共の一速の基礎実駼の結 果以下の結論学得たのであります。実跧法，データー の詳細は1962 年の First International Congress on Chem. Eng., 1960 年の C.E.P., 1966 年の硫安技 術などをご参照下さい。

1）共役二重結合を有するジェン類でもる 1,3ブタ ジェン拈よびシクロペンダジンと窒素酸化物との反

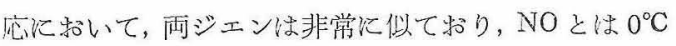
以下で発火するような不安定な化合物の生成は認めら れなかった。

2) 所が空素酸化物が $\mathrm{NO}_{2}$ または $\mathrm{NO}$ と $\mathrm{O}_{2}$ との 混合物の場合は, $-100^{\circ} \mathrm{C}$ 以下という低温でも液化岸 
化水素を溶媒として反応を起し，不安定な自然発火性 の化合物を生成することを確認した。

3）この化合物の組成は単一でなく, 自然発火点を $-100^{\circ} \mathrm{C} \sim+100^{\circ} \mathrm{C}$ 間にもつ化合物を含む数種のもの からなる。

4）この化合物は液体炭化水素などで湿った状態で は比較的安定であるが，液体炭化水素に対して窒素酸 化物が多量飞存在する場合, 乾いた場合は非常に危険 で， $-100^{\circ} \mathrm{C}$ 以下でも自然発火し得る。

5）この化合物の爆発威力は極めて大きく, 僅か 10 $\mathrm{g}$ 以内で, 大きな爆発音を伴いガラス管を破壊し, 内 径 $8 \mathrm{~m} / \mathrm{m}$ 外径 $10 \mathrm{~m} / \mathrm{m}$ の銅管を圧潰した。

6) エチレン, プロピレン， $\alpha$-ブチレンなどのモノ オレフィン類は窒素酸化物とは低温で殆んど反応しな いことが判った。

7）プロ パジェン，アセチレンの低温に拁ける $\mathrm{NO}_{2}$ との反応性はモノオレフィンと大差ないことが判っ た。

8）また窒素酸化物とジェン類との反応生成物の液 化炭化水素に対する溶解度は余り大でなく, 殆んど沈 澱物となることも判った。

\section{液体窒素洗條装置内の NO および炭化水素の 挙動}

私は先に低温自然発火性の反応生成物は $\mathrm{NO}$ とジエ ンとの反応では生成せず， $\mathrm{NO}_{2}$ または $\mathrm{NO} と \mathrm{O}_{2}$ との 混合物との反応に扔いての反生成するとい5実験結果 を申し述べた。したがって実際の装置内でこのような 反応が起るとすれば，ガス中の NO はまず酸化せられ て $\mathrm{NO}_{2}$ となる必要があります。

液体空素洗滌装置に入る前の原料ガスは約 $0.01 〜 1$ ppm の NO を含有しております。このNO は共存す る $\mathrm{O}_{2}$ によって酸化される訳でありますが，一般にこ の酸化が気相で起るように認識されていました。しか し気相に括ける酸化はかなり長時間を要し, 実際上装 置内を通過する高々 1 2 万に気相で酸化される NO 量は極めて僅かであります。我々の行なった実験でも, NO $1 \mathrm{ppm} ， \mathrm{O}_{2} 0.5 \mathrm{ppm}$ を含吉合成コークス炉ガスを, ただしこの場合ジェン類は入れて和りませんが，10〜 $25 \mathrm{~atm}$ の下で数分間滞溜させて，NO の酸化率が数\% 以下であることを確認して和ります。

ところが実際の装置では酸化反応速度恒数を基とし た計算值よりも，また今述べた実験結果よりも遙が 多量の NO が, 個々の熱交換器内で減少していること
またこれらの熱交換器の凝縮液中に存在する窒素酸化 物は $\mathrm{NO}$ でなく $\mathrm{NO}_{2}$ であることが分析で確認せられ て挍ります。この 2 つの事実は，まず第 1 にNO の酸 化は気相ででも起るが，大部分は液相で起るというこ そ, 第 2 そジェン類なぞの触媒作用により NO 酸化速 度が加速されるのであららということを示唆して拉り ます。この場合, 接触酸化の温度係数は負であり, 反応係数は温度が下るほど増大する上，接触作用によ り, $\mathrm{NO}_{2}$ の濃度が増大する泀ど液化量も增大するとい 万点は，特に注意を要します。

このようにNO 拉よびジェン類を含む多成分混合ガ 大の低温での相变化が，NO の酸化速度に重要な役割 を演じていることが想像されるが，装置内各部の分析 結果と, 気液平衡関係からの推算によって, 装置内の NO 特よびジェンの挙動を探ってみると，ガス組成に 上り差はあるが，ブタジェンはプロピレン溜分とェチ レン溜分に溶解するが，NO はプロピレン溜分には余 り溶解せず，エチレン溜分とそれ以下の溜分で液化溶 解することが判った。

以上のことから， $\mathrm{NO}$ は主として液相中で $\mathrm{NO}_{2}$ に 酸化せられ，ブタジェンと $\mathrm{NO}_{2}$ との反応生成物は主 そしてェチレン溜分中で生成し，場合によっては，プ ロピレン溜分中でも生成すると考兄られ，先の温度範 囲は略 $-100 \sim-160^{\circ} \mathrm{C}$ 程度，したがって操業監視を 行なう必要のある機器は，エチレン溜分の生成する熱 交換器拉よびエチレン溜分の蒸発する熱交換器である とい党すす。

\section{爆 発防 止法}

1）装置にガスを入れる前で $\mathrm{NO}$ または $\mathrm{NO}_{2}$ 抢よ びジェンの中の一つまたは全部を除去する方法で接触 水添法, 吸収法, 吸着法, 加压酸化法等々であります。 2）装置の設計上，操作上工夫をこらして爆発を防 止する方法で，これには $\mathrm{NO}_{2}$ とジェン類の反応生成 物が蓄積しないような機器の構造的工夫, 熱交換器の 切換洗滌, 心るいは熱交換器の温度变動をなくする操 作または NO 許容量の設定等々で，これは空気分離装 置のアセチレンによる爆発防止法と酷似しています。

以上，低温分下分離装置の事故原因と安全対策の一 例として, 液体窒素洗滌装置の NO に上る爆発のみに ついて間題をし涪り，原因と対策について述べをした。

しかし低温ガス分離装置としてはこの外取扱ガスが 可然物であること，場合によっては毒性ガスであるこ と，山るいは高圧，低温という条件で操業することな 
どから具備しなければならぬ設計，製作，操業上の基 本的な安全対策があります。何れにしても各事業所が 公共の安全を守るといら大きな社会的責務を果すた
めにも，設計製作しまたは操業する低温ガス分離装置 の規模とプロセスに応じた適切な安全管理体制を確立 し，事故を防止する必要があります。

\section{低温実験室と和ける事故例とその安全対策 I}

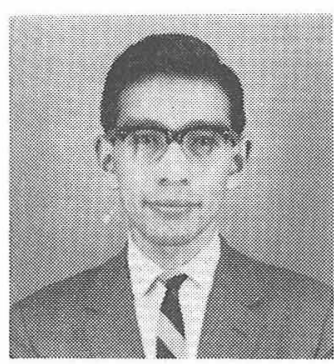

小林嵿夫氏
私共の東大低温センタ 一は，全学液体へリウ 么, 液体水素及び液体窒 素を供給するのが主な役 割です。私共のーリウム 液化機は，わが国にあり ますものの中最も大き く，また，東大炕打る 唯一の工場的規模をもっ た組織です。しかしこの低温センダーは発足してから まだ 2 年しかたっていませんし，それにオペレーター も訓練中であり, 全力生産をするに至っていませんの で, 現在までにこのセンダーの機器の設置及びオペレ ーターの訓練などに関し, 私達が払った注意及び経験 をお話しして皆様方の参考供したいと思います。乙 たがってこれらのことは会社の方々にとっては, 当然 すぎることばかりかもしれませんが，これからは東大 に扣けるものと同等の，もしくはそれ以上の規模の低 温機器が大学炕, また研究所火続々と設置されること と思いますのでそのような方々に, 私達の実情を知っ ていただいて，打役に立てたいと考光ます。

さて今日のテーマである低温工学の安全性というこ とですが，私達の低温センターに関しましては，この 安全性，言いか点ますと危険を防ぐといらことは大別 して二つに分けられます。第 1 は液化機操作上の危險 性であり, 第 2 ののは, 低温液化ガス取扱い上の危 険性であります。まず第 1 の液化機操作上の問題は, 液化機が圧縮機，高压ボンベ及び高圧配管，弁などを 含さので高圧ガス取扱いのことになります。取报らガ スは主としてヘリウムで, ガス自体は不活性で宓るた め, 水素, アセチレンの栐な危険はめりませ九。水素 液化機の場合は特別に注意が必要ですが, この点に 関しては，後程に述べせていただきます。

第 2 の液化ガス，特に液体へリウムの場合の危険性 は，ガス自体の危険性は，大量に蒸発して，空気中に
小林嶺夫

充満して窒息するような場合を除き，ないと考えられ る。問題は, 液化へリウムの気化の潜熱が他の液化ガ スの 100 分の 1 程度で非常に蒸発し易く, 貯蔵容器の 破壤等の事故時に大量の熱流入があると急激な蒸発が 起こり, 約 800 倍にも膨張するので, 爆発に近い現象 を起こすことがしばしばあります。をた，圧力による 沸点の变化も, 老の係数自体は小さいにもかかわら ず, 沸点が $4.2^{\circ} \mathrm{K}$ と低いので, 沸点烧する変化率は 大きい。ゲージ圧 $1.26 \mathrm{~kg} / \mathrm{cm}^{2}$, 温度 $5.25^{\circ} \mathrm{K}$ の三重 点には，外的条件の变化により容易に達することがあ り, 液体へリウムの密度が温度により, 大きく変化す ることとからんで, 大量の液体へリウムの貯蔵は問題 点があります。加圧された液体へリウムは減圧時に大 量蒸発します。例壳ばグージ圧 $0.5 \mathrm{~kg} / \mathrm{cm}^{2}$ に加圧さ れた液体へリウムは, 大気圧に減圧すると約 $20 \%$ む が蒸発してしまいます。この蒸発により, 容器の口付 近は, 大量の液体空気が出来て引火, 爆発の危険が生 じます。をたこの蒸発低温ガスにより凍傷をおこすこ とがあり大変危険です。

この大量蒸発または気化時に容器が密閉されて括 り, 安全手が働かない, または, ガス出口が不注意に 上り空気中の水蒸気が谏結してふさがっているような 場合には, 容器内圧は高压になり, 爆発をおこすこと があります。

次に私達の安全対策を扣話したいと思いますが, そ の前に低温センターにどんな低温設備があるか簡単に 述べて扣さます。

設置されている最大の機械は, ヘリウム液化機で, 液化能力は毎時 25 立以上, 使用ヘリウム压縮機は 2 台めって, 午の能力は夫々吐出圧, 吸入量が $11 \mathrm{~kg} /$ $\mathrm{cm}^{2} \mathrm{G}, 750 \mathrm{~m}^{3} / \mathrm{hr}$, 及び $13 \mathrm{~kg} / \mathrm{cm}^{2} \mathrm{G}, 550 \mathrm{~m}^{3} / \mathrm{hr}$ で す。へリウムガス回収, 精製装置は, 吐出圧 $150 \mathrm{~kg} /$ $\mathrm{cm}^{2} \mathrm{G}$, 吸入量 $60 \mathrm{~m}^{3} / \mathrm{hr}$ の压縮機を使用 $\mathrm{L}$, ヘリウム ガス高圧貯槽は, 使用圧 $150 \mathrm{~kg} / \mathrm{m}^{2} \mathrm{G}$, 内容積 $133 l$, 長さ約 $4 \mathrm{~m}$ のものを 40 本用い, 約 $800 \mathrm{~m}^{3}$ のガス貯 
蔵が可能です。このガスは，液体へリウムの換算に約 $1000 l$ になり京す。次に水素液化機は, 安全第一を設 計の方針にしたため，水素ガスと冷却系は別サイクル となって㧊り，水素ガスは加圧することなく減圧弁侣 よりへリウムガスによる彾却系と熱交換して液化する 方式をとっています。以上がセンターの持つ主な機器 です。

センターとしての安全対策は，いろいろやって物り ますが，まず第一にオペレーター教育は，高圧ガスの 性質, 高圧機器, 低温機器汇関して定期的なものの他 飞, 随時必要に応じて, その都度教育を行なっている す。第 2 亿機器の定期点検は，液化機に関しては運転 前及び運転後に必ず点检を行なって安全を確認し，ま た運転中は 1 時間每に機器各部の圧力, 温度などを測 定記録し, 音響振動等, 異常の有無をたしかぬている。 更飞記録計火以上の事項を記録させて，両省を比較確 認を行なって, 敬障, 異常の発見及び防止につとめて いる。第 3 に運忶要員汇関しては，液化機の安全装置 は一応完備してはい昰すが，原則として 2 名以上で行

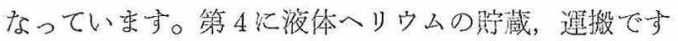
がセンター内には $250 l$ の容器汇常時 $100 l$ 以上䁚藏 されており,この容器は $10 \mathrm{~kg} / \mathrm{cm}^{2} \mathrm{G}$ 以上の内圧では 2ケの大きな安全并が開くようになっていなす。実験 者に液体へリウム分分配するときは，30l 程度の小型 コンテナに分配後，小型トラックにて運搬するが，そ の際は必ずセンターの液体ヘリウムの取扱い䒚知し たオペレーターを同乘させ，取扱いをすることにして
いる。第 5 に液体水素の貯蔵及び使用に関してです が，貯蔵は原則として金属デュワーによっていぬす。 この容器にはトラップがついて物り逆止升を併用して 外気及び氷蒸気の吸入に上る事故防止起かってい宋 す。液体水素は，七ンタ一内の水素尃用吼った実 験室以外での使用は許可しておりません。この実験室 は約 2 分に 1 回の換気速度で新鮮な空気を吸入して, 水素が充満するのを防いで扔ります。また，水素使用 中は必ず水素探知器を動作させ, 室内の水素濃度を測 定，記録計にて記録して物ります。

最後に高仼ガス取締法に関して関係の方に頻いが あります。一つは，この法律液体へリウム及でその 液化について，これに関連の条文を決妙ていただきた いこと。もう一つは作業主任者関してですが，私共 のような大学, 官庁については特例を設りてほしいこ とです。高圧ガス取締法は私達もその法律を尊重し, その規準に合らように機器を設置, 運用しておううす が，とにかく現在は，作業主任者なしで，いわば無認 竫運転を行なっている現状です。もし私達が作業主任

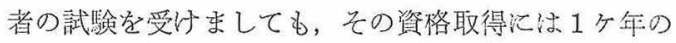
経験を有しないということで，資格はもら学ず，大学 飞执いては会社の有資格者学給料の安い大学汇引拻い てくるといらことをしないかぎり，いっまでたっても 液化機器の運転は不可能汇なってしまいます。この様 な点に関して，関係者のご意見宓お聞さしていと思い ます。

\section{低温実験室における事故例とその安全対策 II}

早坂㤵一

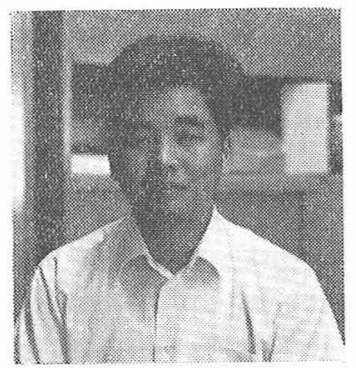

早坂啓一氏
紹介戴きました早坂で ございます。まず物性研 究所液化室の見状をご紹 介致します寸。物性研究所 液化室は物性研究所の創 設と同時に出発し，その 建設には，大島教授（現 工学部), 永野助教授が尽 力され，その後，菅原教 授，田沼教授と变わられ，今日では菅原教授が最高責 任者になっておられます。現在製造している液化ガス
は，液体ヘリウム，液体水素，液体空気ですが，ヘリ ウム, 水素の增加に伴って, 液体空気の供給が追いつ かなくなっています。スタッフは8 名で, 寒剂の慗 造, 供給, 保守, ヘリウムガス精製などの仕褧で, か なり忙しい状態です。予算, 計画, 設䟮, 人事など, 票営に関する方針は, 低温委員会が決定します。低温 委員会は，教授，助教授数名で疅成され，乙れの実行 は委員長が行なって拈ります。委員は交替制ですが, 液化室と関係の深い極低温, 固体核の両部門から必ず 委員が出るよう配慮されています。現在の委貣長は菅 原教授です。 
設

備

フィリップ社製の四気筒（モデル B 型）一基がめり ます。貯槽として $800 l ， 2000 l$ ，それ艺れ一台女りま す。最近增加が著しいので, 需要をなかならのに液体 窒素を外部から購入して補って招ります。その為の専 用粽槽として，6000l一台が㐫りをす。その他コリン ズ式へリウム液化機法二台市り, 一台の能力は $10 l /$ 時 です。国産のカスケード式へリウム液化機 $(6 l /$ 時) が 岕り李す。この装置は, 液化機の設計, 熱量計算など 全て自分達の手でとい5方針で大島教授, 永野助教授 らによって昭和 33 年, ヘリウム液化に成功した国産 1 号機です。これは一つの装置内で, 液体室素を減圧 して冷却し, 液体水素を作り, この液体水素を冷却郕 として，ヘリウムを液化する階段式方式です。自由膨
張だけを利用するこのやり方は液化効率は劣りますが 低温部に郝ける運動部がないので，故障は少なくない です。現在はこの装置を一部改良して, 液体水素を採 って括ります。物性研究所は共同利用研究所なので 共同利用で外部からこられて, 寒剂圶使用される方も 逐次增加してきています。外部の方で直接寒凨を持ち 出さ机る場合は, 低温委員会委員長に申乙込み, 所内 の研究室で寒剂を使って実験される場合は, 部門の所 員汇連絡をとり共同利用申し込反の手続をとって戴く 様沈っております。設備の概浼及び活動状況をご紹 介致しましたが, 研究所の活動が急ピッチであるので この所, 寒剤の使用は毎年確実に 30\% 堌加していま す。

貯蔵とトランスファ技術

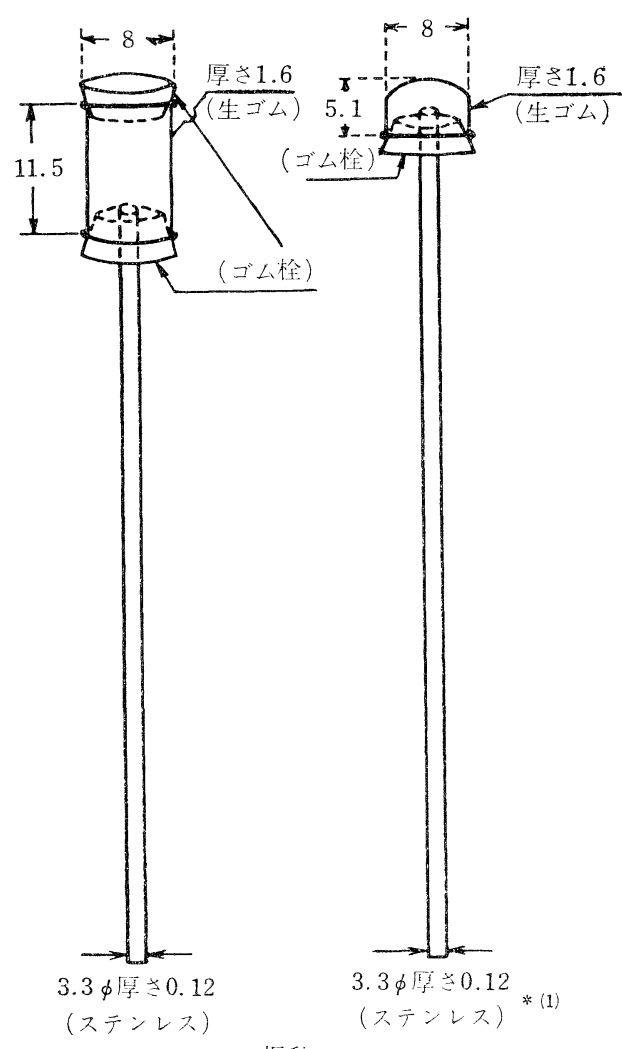

振動

(b)

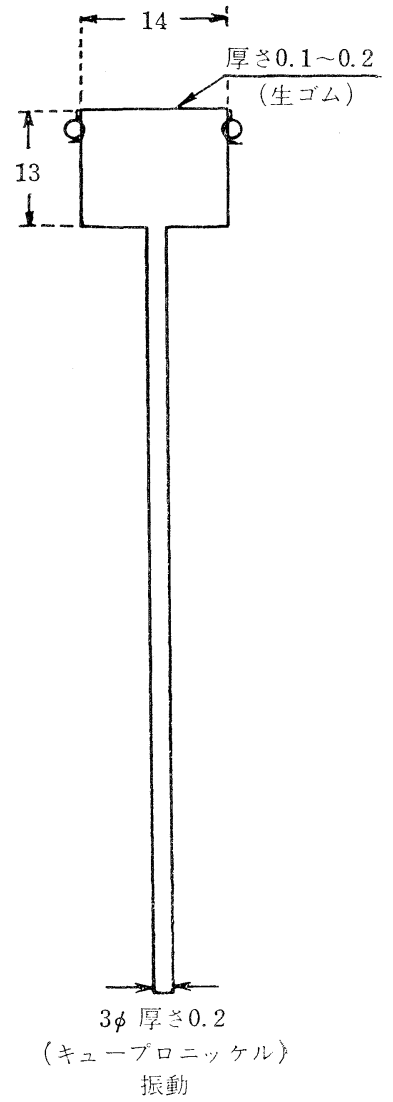

(a)

図 1 液面計

Vol. 3 No. 4 (1968) 


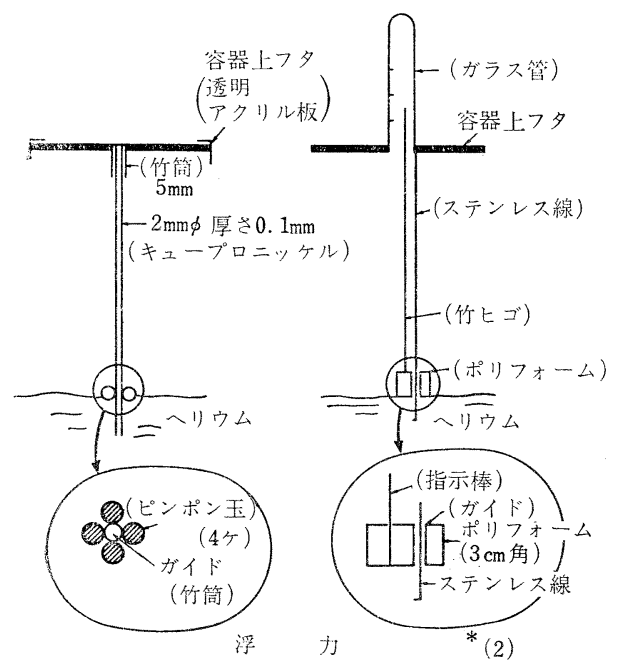

(b)

図 2

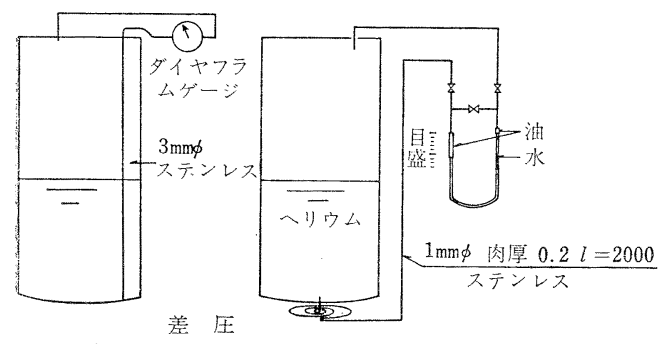

(b):

(a)

図 3

液化ガスの潜熱を考学て，貯蔵，移送，共に時間当 りの蒸発量を最小炕する必要があります。最も良く用 いられるものは, 真空断熱であって，それは気体によ る熱伝達を小さくすることが出来をすが，熱輻射はさ けられません。輻射に上る熱伝達を少なくするため容 器の内面をメッキにします。大量の場合は多重層断熱 や粉末断熱が使われます。液体水素の場合は液体へリ ウムと同じでめります。普通液体窒素でまわりを覆っ た二重デュワーが用いられ，容器などにもよりますが， 空の状態では約 $1 \%$ 位の蒸発量です。液体水素はオル ソーパラ変換により反応熱 $(310 \mathrm{Cal} / \mathrm{mol})$ を発生し, 蒸発熱 $(213 \mathrm{Cal} / \mathrm{mol})$ 上り大きく一日で $30 \%$ 位が蒸 発してしまいます。したがって長期間液体水素を貯蔵 するには, あらかじめ液化機に触媒を入れ, パラに転 換して和く方がよいと思います。トランスファサイホ ンは，ガラス製と金属製がありますが，ガラスの場合

液体水素に使用する場合特に注意しなければなりませ ん。これは表面のメッキに触媒作用があり, 事故の際 は危険だからです。へリウムの場合は洩れがなければ 真空が少々悪くても間題はありません。残留している 気体が固化して高真空になるからです。しかし時及常 温ではなんでもなく，冷觉るとリークすることがあり ます。金属へリウムクライオスタットに今迄へリウム が簡単に溜っていたのが，急に溜らなくなった場合は まずこれに間違いはないようです。検査方法は片方に 真空計をつなぎ，窒素槽に徐々にクライオスタットを 沈めて行き京すと、リークがあれば，その所で真空計 の針が振れ簡単飞洩れ個所がわかります。比較的簡単

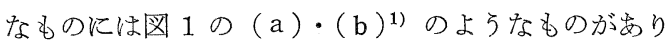
ます。液体を注入している時のように内部で沸騰して いる時は図 $2^{2)}$ 図 3 を使光ば，かなり正確に測れるの で便利であります。

\section{低温の液体を扱う場合の注意}

一般に低温の液化ガスを取扱う場合に注意する点は 皮膚に触れると凍傷を起こす危険があることです。実 際に液そのものを手などにかけても，少量ならば液が 蒸発し，ガス膜が出来て保護するので，何んでもあり ません。むしろ冷却したものに触れる方が危険があり ます。実験用クライオスタットは, 大抵ガラスの容器 を使用しますが，しばしば割れるので眼を保護するメ ガネをかけた方が良いです。容器を一度使用しますと 器壁に水分が凝結して使用後に水が残ります。この水 を棒の先に脱脂綿などをつけ吸取り，水分を除かない と氷結の際の澎張によりガラスが割れることも出り字 す。液体水素, 液体へリウムなどのクライオスタット を液体窒素で予泠する場合も大量の液体窒素が残らな い様に注意すべきです。液体窒素や液体へリウムなど の気体は, 化学的には全く安定していますが, 暖かい 物体に触れると蒸気してガスとなり，その際体積が数 百倍になりなす。この蒸発が急激に起こると部分的に 異常圧が生ずるので, しばしば容器が破壞したりして， ケガをします。液体酸素は有機物, 特に油分の付着し たものは, 絶対に危険です。蒸発したガスは, 比重が 大きいので地上を這って拡がります。液体空気は裂造 直後に使う場合は良いのですが，古い液体空気を使う 場合, 酸素に富んだものとなり液酸同様の注意が必要 です。一般に低温液体を使用する場合は, 蒸発するガ ス口をふさがないようにする事が大切で，水分や時に は空気が固着すると大変な事故となる例がありますの 
で, 出口にはトラップを置き,トラップ内の不然性汻で 外気をしゃ断すべさであります。物性研究所では液体 水素を製造して打りますが，それを例にして述べて見 たいと思います。液化機運転中は漏洩に注意し強制換 気（1 分間に 1 回，室内の空気が換気できる大型換気 装置）で通風を良くしています。コンクリートの厚い 壁で周囲をかこい，天井をなるべく高くしスレートぶ きにして扮き，飛びやすい構造にして捛き，水素を減 王する場合の真空ポンプの油は不燃性油を使っていま す。一番問題になるのは静電気ですので, 床は電導性 のあるものを使用しなければいけないので，適当に水 などをかけて電導性を良くしていすす。Boulder では 作業中頭の毛をかき上げてはいけないとか，ナイロン 製のものを着て仕事をしてはいけないとかいった作業 する人の服装まで規制して注意しています。勿論, 電 気のスイッチ，電登などは全部防爆型を使用していま す。作業するスペースも事故防止に役立つそろで，一 つの実験をするのに少なくとも $13.5 \mathrm{~m}^{2}$ (4 坪) から $18.0 \mathrm{~m}^{2}$ ( 5 坪) 位のスペースは必要であるといってい る人るいる位です。最後化物性研究所の水素取报規定 の一部起ご紹介して扣きすす。

（1）液体水素を使用する場合は，一件毎にあらか じめ使用計画や装置に関して, 低温委員長の点検を受 け承認を得ること。

（2） $3 l$ 以上の液体水素は, 低温委員会の指定す

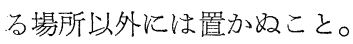

（3）蒸発するガスは必ず，室外大気中，または防 爆水素吸引管 $\left(\right.$ 図 $4^{3)}$ ) を通じて放出すること。

（4）放出する際，ガラス製の逆流防止器を挿入乙 て蒸発ガスが正常に放出され, 室内に漏洩していない ことを確認すること。

（5）逆流防止器には不然性油を用い, 屋外の大気 中に放出する場合は放出口より $50 \mathrm{~cm}$ 以上離し, 水素

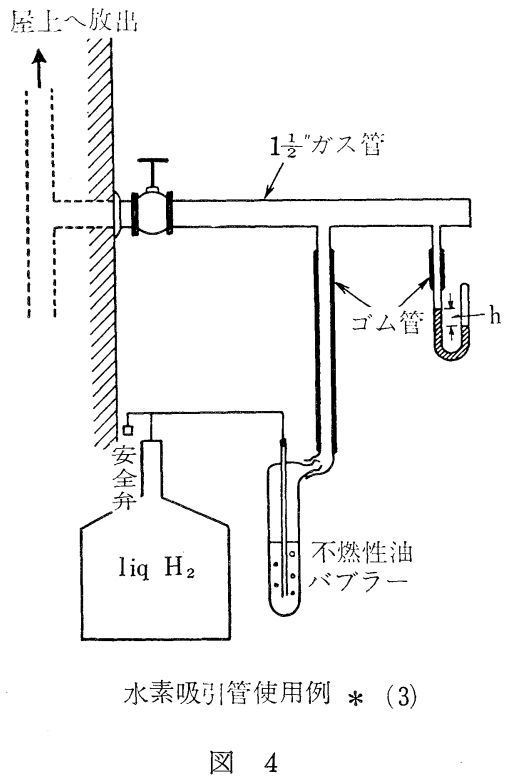

が安全に拡散する様に留意すること。

（6）室内には火気や爆発の危険を導びく様な物体 を置かない上うにする事。殊にモーターその他の電気 器具が天井に近い場所にある時, 電気器具の火花防止 には万全を期すこと。

（7）液体水素使用中と朱筆した危険表示索必ず行 ならこと。

以上で終りますが，甚だまとまりのない話であった ことを拉詑びします。

\section{参考 文 献}

1) T.R. Kyle : Bell Tel. Lab. March 23. 1967.

2）確井節夫：物性（1965） 5 月号. p. 257 .

3）宾倉錬：低温週報（1961）第 113 号.

4) 白上, 黒木, 村上, 矢野: (物性研究所) 私報, (1960） 2 月. 


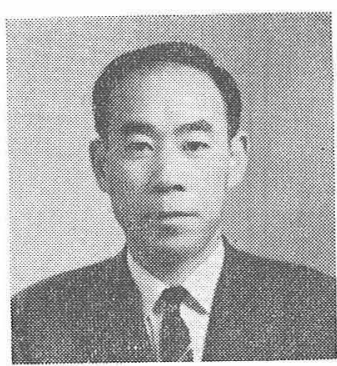

等从力 详氐
私共では液体へリウム の翰送とか大量の崛蔵は

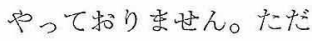
$250 l$ の ADL 社のコンテ ナは使って扔ります。私 共でやっている MHD 発 電用の殡形超電導磁石に 関連しました安全刘策の 蚛話をいたします。先程 司会の大島先生から叔話が步りましたが，磁石の蓄積 エネルギーが相当大きくなった場合に，何か安全対策

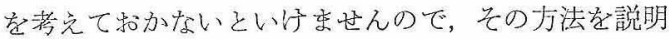
したいと思います。超電導磁石が大型化しますとこ れに蓄積されるエネルギー $\left(\mathrm{LI}^{2} / 2\right)$ が非常に大きくな りょすので, 磁石が超電導から常電導に転移したり， めるいはデュアーの真空が急に劣化するということに なりますと，大量の液体へリウムが急速に蒝発します
等々力達

ので，当然气の対策を考えて置かなければならないの ですが，ここで申し上げる方法は常識的なるのでして それがをた，世界各所の大型超電導磁石を計画してい る研究所なぞで䒠際荐点られている対策であるよう です。

第一にデュアーの真空の劣化の間題ですが，これは 大型の装置では非常に危険なことなのですが，特に対 策というものが岕りません，強いて言えば，真㘹ポン プの引き口で京，デュアーの運転中はなるべくバルブ を綿め切る，真空ポンプを引きっぱなしKしないよう にして，真空ポンプの故障をデュアーの方へ波及させ ないようにする。ぬた，磁石が大型になりますと，デ ェアー外へ強い磁界が出势すので, 真空ポンプを連続 運転する場合には，ポンプの材質も非磁性体のものに するということを考党なければなりなせん。

第二に磁石エネルギーを転移発生時に，常温部の抵 抗へ移してやることが必要です。それからデュアーの

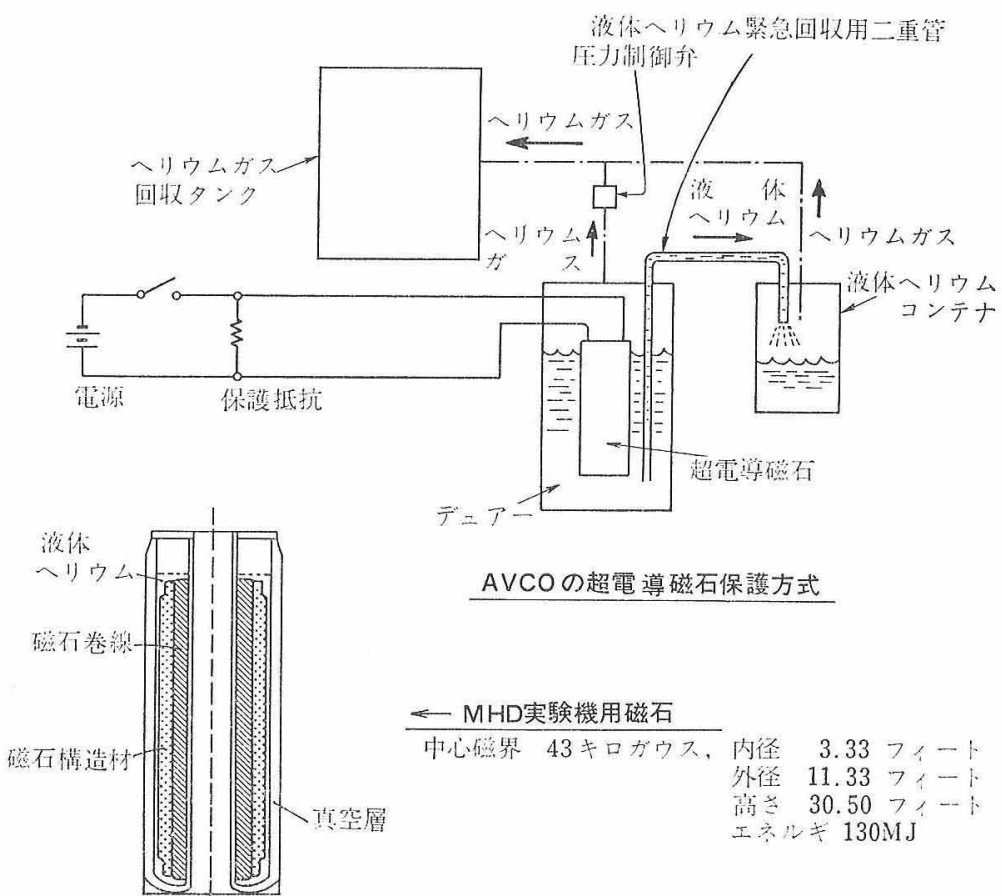

図 1 
内压上昇に対して安全弁，破壞弁などの安全装置をつ けることは当然です。

第三に，これは日本では未だ実施例がないんじゃあ ないかと思いますが，常電導転移が始をったならば， 液体ヘリウムをコンテナへ急速に逆送してやることを アメリカでは計画しています。

四番目としましては, 少し先の問題かと思いますが デュアー内に貯める液体へリウムの量を少なくするた めに，液体へリウムを強制循環させてやるか，女るい は冷却へリウムガスまたはミストの循環で泠却する。 こうすれば，エネルギーが大量に放出されても爆発の 危険がなくなる。目下のところでは，このような対策 が考光られて和ります。

図1は昨年の京都の会議で AVCO 社が発表した計 画です。一緒に MHD 実験用磁石も示しましたが，こ れは未だ製作にかかってはいない上らです。デュアー の真中に MHD 発電用の中空部分がありまして，その 直径が約 $1 \mathrm{~m}$ 位で, 外径は約 $3.4 \mathrm{~m}$ あります。この 装置の安全対策としましては，まず電源から電流を供 給するスイッチを切って, 磁石エネルギーをデュアー 外の抵抗に 2 分以内に移します。それと共に蒸発へリ ウムガスの圧力を検出しまして，コンテナーへ液体へ リウムを急速に逆送します。これは戝に書いてあると ころでは簡単ですが，実際には，コンテナの方の圧を ぐっと低くしてやらないと大量の液を急速に移すこと は，難しいと思います。

2 年程前に同社では $40 \mathrm{kG}$ の鞍型磁石の実験をや

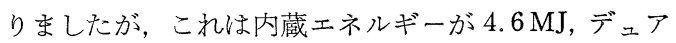
一は高さ約 $5 \mathrm{~m}$, 内径 $1.5 \mathrm{~m}$, 液体へリウム張り込み 量 $2800 l$ といら大規模なものです。この磁石には安定 化超電導線を使いましたので, 安定に運転が行なわれ まして, 約 785 A で常電導が発生しましたけれども, 電流を減少してやれば再び超電導に戻るということで 一時に大量の液体一リウムが蒸発したというょうな話 は聞いて括りません。それから、このデュアーの安全 装置は安全弁に頼って和りまして，まず絶対気圧の 1.1 気圧でアラームを出し，20 秒後に弁を開さむし て, 大体 $7.5 \mathrm{~cm}$ 直径のパイプで蒸発ガスを逃がして やる。次に 1.7 気圧でスプリング動作のリリーフを働 かせる。これでも更に圧力が上昇する際には 1.8 気压 で破壊弁が働き直径 $10 \mathrm{~cm}$ のパイプからガスを放出す る。このような安全装置がついて物ります。

それから，米国アルゴンス国立研究所で建設中の水 素泡箱に使用する超電導磁石は, 皆さんもご存知のよ
5に蓄積エネルギー $80 \mathrm{MJ}$ で，デュアーも直径約 $5 \mathrm{~m}$ とい5巨大なものですが，安全対策としましては，ほ ぼ AVCO と同様の方法が予定されているようです。 私の感じでは, 常電導転移の場合には, 液体へリウム の外部への逆送は, 磁石自体の温度上昇を招き, 次の 運転に支障を来たすので，外部抵抗へ磁石エネルギー を移すのが一番良いのではないかと思います。この方 法は永久電流モードで運転している場合でも, 短時間 のうちに外部抵抗へエネルギーの大部分を移すことが 可能です。

以上述ベました AVCO とアルゴンヌ国立研究所の 例は，銅母材中に超電導線を埋め込んだ安定化超電導 線で作った磁石の場合ですが，それ程安定化が十分で ない超電導撚線の磁石の場合に，相当量の液体へリウ ムが蒸発したという報告がありますので，それをご紹 介したいと思います。それはスタンフォードの線型加 速器センター (SLAC) の超電導磁石で, 重量 1.6 卜

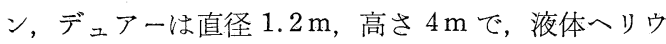
ムが $400 l$ 入って扔ります。この磁石の実験中に，常 電導転移が発生しまして, 約 10 秒間に $350 l$ の液体 ヘリウムが蒸発したそうです。この時の磁石のエネル ギ一は, 呿掠よそ $2 \mathrm{MJ}$ で, 安全弁が動作して, 蒸発 ガスを大気へ放出したものと思われます。このデュア 一には, $4.5 \mathrm{psi}$ で働く直径 $12 \mathrm{~cm}$ の安全弁がついて 抒りましたので, デュアーに異常はなく，引き続き実 験が継続して行なわれたようです。

同じょうな超電導撚線を使った磁石の実験は,フラ ンスのサクレー原子力研究所でも行なわれまして, 約 $400 \mathrm{~kJ}$ のエネルギーを持った磁石に常電導転移を生じ させたところ，巻線の一部を焼損致しました。液体一 リウムによるデュアー内圧の上昇は，たいしたことは なかったとらです。その後，磁石エネルギーを外部抵 抗へ移さ称ばいけないといらことで, 種々検討を加党 た結果， $2 \Omega$ の抵抗を使用することになったそうで す。

次に私共でやりました超電導磁石の常電導転移時の デュアー内压上昇について和話したいと思い李す，一 つはパンケーキコイルの実験ですが，これは内径 6.5 $\mathrm{cm}$, 外径 $21 \mathrm{~cm}$, 高さ $17.5 \mathrm{~cm}$ で, AVCO の SG500 という安定化超電導線を使って抲ります。デュア 一は内径 $22.5 \mathrm{~cm}$, 高さ $132 \mathrm{~cm}$ です。このコイルは 磁界がそれ程強くなかったので, 約 $800 \mathrm{~A} て ゙$ で転移いた しましたが，この時のデュアー内圧をがイヤルチャ一 卜式圧力計で記録致しました。コイル電流を増加して 
ゆき五をと, 約 $350 \mathrm{~A}$ で, 内压は水柱 $500 \mathrm{~mm}$ 位に なり, $750 \mathrm{~A}$ では水柱 $1000 \mathrm{~mm}$ を越えて, どんどん 上昇致します。これはコイル電流黄供給するリード線 (蒸発へリウムガスで椧却している) からの熱侵入が どんどん增加する為だと思われ㿟す。遂に $800 \mathrm{~A}$ 付近 で常電導転移が始まりをすと，内圧は急泣ち上りな す。水柱 $2000 \mathrm{~mm}$ 位で, 安全并（直径 $10 \mathrm{~mm}$ ) を䦥 いてやりますが，压力は，な打上昇を続け，転移発生 後約 1 分で, 最大水柱 $3800 \mathrm{~mm}$ を記録しました。こ の時は, 転移発生後, 徐々飞電流を減少し, 電源を交 流側でしゃ断したのは転移発生後，約 10 秒でしたの で, 約 $20 \mathrm{~kJ}$ のエネルギーがデュアー内で消費されま した。

次に鞍形超電導磁石の実験では，外部抵抗へのエネ ルギー移行が比較的うまくゆきをしたので，その模様 を报話し亦す。この嗞石は有効内径 $27 \mathrm{~cm}$, 高さ 90 $\mathrm{cm}$, 使用した超電導線はパンケーキコイルの場合と 同じ SG-500 です。デュアーは内径 $82 \mathrm{~cm}$, 高さ 250 $\mathrm{cm}$ で, 液体へリウム張込量は約 $350 l$ です。安全弁 としては，0.45 気圧 (ゲージ) で回収用バルーンへ, 0.5 気圧で大気放出用が動作するようになって和りま

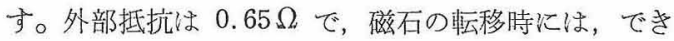

\section{安全管理法規と基準}

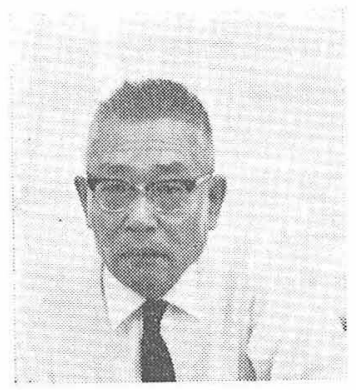

石井尚道氏
高压ガス保安協会の石 井でございます。先ほど 加ら皆さんの扣話を大変 與味深く扯聴さ她ていた だき, また低温工学の特 殊性から, その各段階が 必ずといって良いくらい

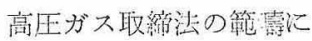
入っていることを承知し まして，この法に直接関係している者として，大変責 任を感じているものでありなす。

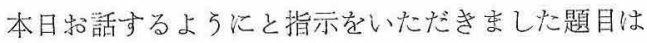
安全管理法規と基準ということでありますが，労働基 準法，消防法めるい怯建築基準法なぞ，いずれも安全 確保のための法律で岕り，当協会のメンバーの会社工 場の方から，高圧ガス取綐法とこれらの法律との間に
るだけエネルギーをこの抵抗へ移して液体へリウムの 蒸発量を少なくしようという計画でした。

常電導転移は，電流 $690 \mathrm{~A}$ で発生しました。この時 も磁界が充分強くなかったので，電流を徐々に減少し ましたが，常電導域の伝播が止まらないので，約 15 秒後に, 外部抵抗を挿入し京した。このように䪹張っ て電流を流しましたので, $100 \mathrm{~kJ}$ 位がデュア一内で消 費されました。この時のデュアー内压子，前の例と同 じ様に測定致しました。安全弁学 0.3 気圧に整定して おき承したところ，転移発生直後の急速な圧力上年時 以後 0.38 から 0.32 気圧の間で十数回動作を繰り返 乙，過度の压力上昇を押さ光香した。同じような実験 を何回加ないまして，転移発生後，数秒以内に外部 抵抗を接続してやれば，磁石エネルギーの90\% 程度 を常温部へ移行できることを確認致しました。

結論として，安定化超電導線を用いた磁石では，か なり大型のものでも，常電導域の伝播は，そろ急速に 行なわれないので，磁石エネルギーの大部分を常温部 の抵抗へ移行せしめることは，それ程困難でないと感 じて和ります。少なくともスタンフォードの例のよう に10 秒間で $350 l$ の液体へリウムが蒸発するといらよ うなことはないるのと思います。
石井尚道

いろいると間題点があると承っていすすが一保安劦会 の立場としてもこれの解決に努力いたして就りをすが 一本日は高圧ガス取締法だけ限定して話を進めさせ ていただきます。

先添で話題になりました案気分離装置めるいはガス 分㕍装置だけにしばって多ましても，本年に入り僅か な期間飞，前者比新いて 1 2 件，後者沈いて 1 件 の事故例が報告されて和り京す。これらはいずれも，

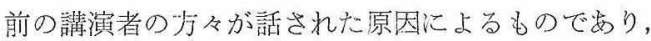
沶話の対策の手が十分にらたれていたならば防止で きたと考觉られるものであります。しかしながら，こ れらの工業的装置の安全管理については, 工場の方多 と当協会との閒にコミュニケーションのルートも㐫り ますので, 時閒の関係も㓟り委すので, 本日は学校, 研究所の方々に，彩迦に説法かも知れ李せんが，高圧 ガス取締法のアウトラインを駆け是でご説明してご理 
解をいただきたいと考光て拉ります。

さて，高圧ガス工業が日本に導入されたのは 60 年 ばかり前で岕りますが，その後相当数の事故が引き続 き発生しましたために，大正 11 年に圧縮ガス液化ガ ス取締法が制定されました。当時の条文は極めて簡単 で監督官庁の任意裁量にまかされた点が多かったので あり末すが，終戦後の新憲法の下に和いては，この任 意裁量は許されず，現在の高圧ガス取締法になったの であります。

法律の名の示すと括り，高王ガスの製造などの行為 は一般的には行なってならないものでめり，特別の規 制の下にだけ，その製造なり取り扱いなどが許される わけで岁りす。

まず法の第 1 条を見ますと，「この法律は，高压ガ スによる災害を防止するため，高圧ガスの製造・販売・ 館蔵・移動乞の他の取り报い及び消費並びに……㕛規 制するとともに…… 女。公共の安全を確保する ことを目的とする」となって和ります。ここでご理解 いただきたいのは，午の後の条項に出ていますが，高 压ガスの販壳に対する規制は高压ガスの販壳を業とす る者, いわゆる販売業者に対してだけの規制になって 括り李すが，製造に対する規制はとの行為を行なう者 て対する規制で，業としなくても規制の対象となる点 であります。

つぎに，一時的に岀るい悈験のためにガスを压縮 したり液化したりして高压ガスを製造する場合はどう かといらことでありますが，これは生縮・液化するガ

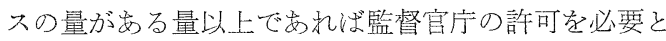
し，その量以下であれば届け出るだけで良く，一時的 試験的のいかんは間い李世九。この点とかく間違いが らでありますので, 研究所, 実験室のご担当の方のご 理解をいたたきたいと存じなす。

それからもら一つ，国の機関の場合はどらであるか

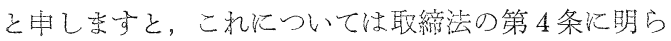
かルされて和り，手数料の規定と罰則の規定を除き， 国の機関にも適用され，ただこの埥合先症ど申しまし
た許可は承認となって和ります。すなわ方，所管の監 督官庁の承衿を得た上で晸造・貯蔵などの行為を行な うわ忾で京りす。

それでは高王ガスの製造について，ぞのような規制 が行なわれているかと申しなす，製造設備を設置す る環境, 設備の構造の設計, 女るい嬠業する場合の作 業について，この取締法に基づく省令である一般高圧 ガス保安規則で 30 数項目にわたって記載されていま す。この各項目の内容の説明は省略させていただきま すが，法令の建て昰えしては，取締法の下に政令で 密る高圧ガス取繶法施行令, 通産省令である一般高压 ガス保安規則・液化石油ガス保安規則・冷凍保安規則・ 容器保安規則などがあります。しかし高圧ガスの䉓囲 は極めて多岐にわたって和ります故，そのすべてにつ いて組かく定めることは不可能に近く, 仮に定めた としてもそれだけで事故の防止は困難で岁りましょ ラ。そこで見在の通産省の考光方としては, 省令汇記 載される表現は市る程度抽象的・包括的な子のとし, 具体的事項恃高圧唯大保安協会を中核とし関連業学界 との協力の下K自主基準を作製し，各慗造者は責任定 もってこの基準に従ってその高圧ガスの彆造を行ない 安全起確保するといら建て李であります。

今との一例是申しますと, 先ほどの空気分離装置に ついては, 装置のメーカー, ユーザーの方々のご協力 学得て「空氮分離装置の検查ならびに維持管理の基 準」を作製中で近く完成する予定であります。

これと同様の間題として，液体水素，液体へリウム の設備委たその取り扱いの保安上の問題点につき,で きますならば低温工学協会のメンバーの皆様方のご協 力を得て, できるだけ完壁な基準を早急见作整して事 故防止に努めてまいりたいと存じます。

取りとめのないことを中し上げ柰したが，与方られ なした時間子多少過ぎたようでありますので，この迅 で私の話を終らせていただきます。ご静聴を感謝いた 七类。 


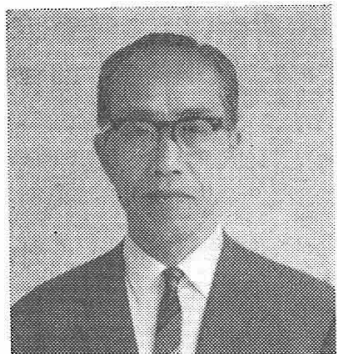

北川徽三氏
最近研究災害という言 葉が出来て扣ります。大 学とか研究所, 試験室の 中で色々な事故が起こる ことを総称して生まれて きたのではないかと思い ます。確加研究室とい 万所は, 新しい研究をや るために，特殊な危険性 を含んでいる所だと考兄られなす。

近代産業の特徴として, 研究災害のほかに, 生産輸 送についても，つぎのような危険があることを挙げら れると思います。

まず第一に，今まで危険性とか，有害性というもの がはっきりわかっていないような新規の物質を取り扱 らことです。

第二に危険な物質を大量に扱うということです。

第三に操業の自動化といらことが盛んになることで す。一カ所に破壞が起さたというだけで全作業が停止 いたします。生産停止というのは非常に大さな損害を 来たすわけです。

第四に極限状態を導入するということです。これが 低温工学に関係がありまして, 非常な高圧, 低温, ま たは高温，高速などを生産工程に導入することになり 特殊な危険が增します。

これらが近代産業の特徴ではないかと思われます。

こういう新しい技術開発していく時に, 研究災害 と同様に, 次の段階として開発災害というあのが起こ りはしないかといらことが考党られます。開発災害を 防止するにはどうしたらいいか。これは法律では取り 締れないのではないかと思らのです。いままで全然な かったよらなプロセスを新しく作るのですから，まだ 法規の条文にとり入れられていない上らなことを工業 化しなければならないといらことになります。

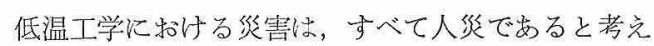
られますので, 原則的には予防可能である。一般に炎 害防止には三本の柱があります。その一つは技術, 次 に教育,さらに規制であります。
北川徹 三

規制には，強制的なものと，衔告的なものとがもり まして, 強制的なものが安全法規でありますが, 法規 を全部守りましても災害が皆無になるということはな いのです。法規は, 最少要求でありますから, それ以 上の対策を施さないと災害は完全になくならないので めります。そのためにはどらすればいいかといらこと を記したものが，自主基準であります。そういう自主 基準または勧告的なマニアルをこれからたくさん作っ てゆく必要があります。

第二は教育でありますが, むず大学の工学部, 理学 部の教育の中に安全という面をもっと取り上げていた だきたいと思います。また教育に伴う研究の中にも， 災害防止を目的とした研究項目がもっと取り上げられ てもいいのではないか, 先ほど申しましたよらに, 新 規の物質の危険特性というものはをだをだわからない 部分が非常に多いものですから，艺ういうものを測定 したり，実験したりすることも研究の非常に大さな部 分をしめなければならないわけです。

最後に技術でありますが.「災害防止は一つの科学技 術である」といら割り切り方をしなければならないよ らになっていいりょした。最近の化学工業界の大事故 を文すを，作業員のオペレーションのミスとい5よ りも，むしろ設計や保全の技術の水準の問題ではない かと思われることが多いのです。生産技術は非常に進 歩して括りをすが，災害防止の技術・安全技術という ものが追随してゆけない状態にある。これが現在の大 工場汇特方事故の原因ではないか，と考光られるの です。逆に，懪発を起こすような工場のプラントは, 本 当の生産プラントではないといってしまえば, 安全技 術そのものが生産技術である。裏を返せば同じものな んですが，ぞうも安全技術の活うは生産技術の付属品 の上ろに思われている。そこに間違いがあるので, 安 全と生産は同じものであると考えなければいけないと 思います。

つざに災害の分類としましては，化学災害とは，水 素などの混合ガスの爆発とか, 酸化性物質と還元性物 質の混合危険とかをいいます。类た物理災害としては 放射線障害とか, 赤外線, 紫外線による眼の障害, 低 
温による凍傷などが考兄られます。また機械災害，土 木災害, 電気災害などといった分類の方法もあるわけ です。

要するにこういった災害を具体的に防止するために は, 従来の学問領域にこだわらない総合性がなければ ならないといらことです。

安全工学には総合性ということが一つの特徴ではな いかと思って物ります。

つぎに低温装置に括ける危険性について二, 三の例 を申し上げてみたいと思います。

1. 低温による材料の脆性のほかに, 升や配管の凍 結による閉塞の問題があって，そのために大きな事故 が起きた実例があります。

これは一昨年の 1 月, フランスのリヨンの近くのフ エザンといら所仙ある国営の石油工場で球形タンクか ら液化プロ パンのサンプリング中に, 直列に 2 個つい ていた弁がともに凍結して閉止できなくなって，霧の 上うに流れたプロパンガスに引火して，球形タンクは つぎつぎに三個大爆発をし，構内は大火事になったこ とがありました。

2. 低温でガスが液化したために危険なガスが濃縮 され，事故が起きた例があります。

昨年の 10 月から 12 月にか子て, 全国で 4 件も同 じような事故が起きました。液体塩素の製造工場で, 塩素中には, 0.2 パーセントから 0.5 パーセントの水 素が混っています。これを約 10 気圧に压縮して, 液 化するわけですが，水素は液化しませんから，ますま す濃縮され，5.5 パーセントが爆発限界ですが，それ が 10 パーセントにも 20 パーセントにもなって, ガ ス爆発を起こすことがあるのです。

3. 液体窒素を使っているときに，低温のために空 気が液化してくる。空気の中の酸素は 21 パーセント ですが，液化すると 55 パーセントぐらいに濃縮され ます。それが可燃性の断熱材に浸みこんだり，可然性 の液化ガスと混ったりしますと，強力な爆発のような 危険な状態になる。そのために大型のガス分離装置が 大破壞を起こし，四散した事故も経験されています。

4. 空気分離装置の液化酸素溜にアセチレンや他の 低級炭化水素類が蓄積して濃縮される。液体酸素に溶 けている場合はいいが，溶解度が小さくて，析出する と危険が生じるわけです。

5. 低温であるがために不安定な物質が安定に蓄積 するということがある。先汪ど戸山さんがご紹介され 李したように，ブダジェンと二酸化窒素の反応生成物
は，極めて爆発性の強い化合物で，ガス分離装置の向 流筒内部に蓄積すると爆発の危険があります。

6. 大島先生もご紹介になりましたが，液体窒素に ガンマー線照射をしているとき，断熱材の発泡ポリス レンが発火したことがあります。液体窒素に触れた空 気は酸素を液化して溶かし込さ。これにガンマ線を照 射しますと, オゾンが生じ, 窒素の蒸発によって濃縮 されてくるわけです。そのとき液体窒素の色が濃い青 色になります。これに可燃性の発泡ポリスレンが接触 しますと，発火するわけです。（菊池，照射実験伴 弓液体窒素の爆発, 安全工学, 4 巻, 2 号, 106 頁, 1965 参照)

7.つざには, 静電気の間題があります。人間は靴 をはいていますが，靴の絶縁性が高いと身体全体が絶 縁状態になりまして，上着を脱いだり，作業着を脱い だりしたときに带電するわけです。靴の抵抗は百メグ オーム以上になりをすと身体は完全に絶縁状態沈り ます。ですから 1 ×グオーム以下の靴をはくことが必 要ですし，他の床材料も抵抗を計って女る值以下にし て执く。あまり低くなると感電の恐れがありますから 感電は防いで，静電気は逃すといったような抵抗值が 女るわけです。その間の抵抗に保つといらことが大切 です。

また液体が流れたときに帯電いたします。ガソリン とか, ベンゼンの汪かに, 液体酸素とか, 液体水素が 流れたときも帯電すると思われます。液状炭化水素の 電導性は，大体比抵抗が 10 の 13 乗オームセンチ以上 位です。それぐらいになると流動に伴い帯電します。 液体酸素, 液体窒素, 液体水素なぞの電気伝導度を計 っていただけないかと思うのです。

8. 歹5一つ特液体酸素のもつ危険性とい5もの があります。液体酸素と油などの有機物や，カーボン 粉末と混合したものは強力な爆発物になります。一般 に酸化性のものと還元性のものを混ぜるときの危険性 を混合危険といっています。

9. 蒸発した低温の液化ガスの蒸気の比重が問題に なると思います。

神奈川県で寒施した野外実験では，液体のプロパン を毎分 20 リットルぐらいら゙つ放出して風下大体何米 ぐらいのところから引火するか実験したところ，大体 30 メーターの距離のところから引火し逆火乙て参り ます。ブタンではこの距離が短くなる。LPGが蒸発し ますと霧が出来，地面をはって風下に拡がりますが， 地上 60 センチぐらいのところから引火することがわ 
かった。ぞの範囲まで引火の危険が书るかといらこと はガスの比重といらことが大切です。

10. 最後に申し上げたいことは, 蒸気爆発とい5爆 発の種類があることです。蒝気爆発というのは，過熱 状態にある液体が平衡状態に戻万うとして, 一気に蒸 気化し，そのために体積が急激に膨張して, 衝撃的な 压力を周囲に及ぼし，強い破壤を起こす現象をいいま す。蒸気压のために高圧になっている容器が急に割れ たとさとか，低温の液体が温度差の女る高温の物体に 接触したときとかに起きすす。LPG タンクの火災と か, 液状モノマ一の重合とか際して，大事故が起き たことが経験されています。同様の現象は低温液化ガ スにもあてはまり, 液体へリウムの蒸気爆発さ光考克
得るわけです。

ガラスのアンプルに液化ガスを入れて販売してなす が，それにコックがついてます。コックが開かなくな りましたので，たたいたところ，つけ根のところで割 れまして，割れた途端に内部の液体が蒸気爆発を起こ しガラスは粉々そなって片目失明した人もあります。 将来はこうした危険な物質や危険の潜んでいる物理 状態をよく知り，管理を綮重にすると同時に，装置， 機械の設計，検查の面に括きむしても安全というもの を十分取り上げていかなければならない。そのために は, 専門の安全技術者といらのが必要になってくるの ではなかららかと考えています。

ります。アメリカでは最初液体水素を運んだとさの規 定を見ますと，前にパトカーをつけて持っていくと畫 いてありますが，日本ではこっそりと見光ないように して運んでいるわけで，どちらがよいかわかりません ケれぞも。(笑)

また，会社の方ですと設計の安全基準の問題があり ます。日本はアメリカなどに比べて，いろいろな点で 問題が岁るように聞いてますので，そういうことも， 低温といら観点から見直す必要があるのではないかと 思います。いろいろな問題が出てくると思いますが， そういうことを一つ一つ取り上げたいと思います。 